\title{
PENGAMBILAN KEPUTUSAN INOVASI PADA ADOPTER PERTANIAN ORGANIK SAYURAN DI DESA CIPUTRI, PACET, KABUPATEN CIANJUR
}

\section{(The Decision Making Innovation of Organic Agriculture Vegetable Adopters in Ciputri Village, Pacet, Cianjur Regency)}

\author{
Maria Ulfah ${ }^{1)}$ dan Sumardjo ${ }^{1)}$ \\ ${ }^{1)}$ Departemen Sains Komunikasi dan Pengembangan Masyarakat, Fakultas Ekologi Manusia, Institut \\ Pertanian Bogor, Darmaga Bogor 16680, Indonesia \\ E-mail: mariaulfah.ipb2011@gmail.com; sumardjo@apps.ipb.ac.id
}

\begin{abstract}
An organic farm continue to be disseminated to farmers, but until now still quite a lot of farmers who do not adopt organic farming. The farmer's decision to adopt or reject the adoption of organic farming of vegetables can be seen from the stage of the decision making process of innovation. This research was done in the village of Ciputri, subdistrict Pacet, Cianjur District. The purpose of this research is to analyze the decision-making innovations on organic vegetable farming adopter and the factors related to the decision making innovation in adopter organic farming of vegetables. This research uses census on the population of farmers who adopting organic farming of vegetables and continue to adopting. The results showed that the level of knowledge adopter of organic farming of vegetables included in the category of being the real factors related to the level of knowledge that is land area and the level of courage to take risks. At the level of persuasion including the high category with tangible factors related to the level of persuasion that is the level of conformance. At the implementation level adopter of organic farming of vegetables including the medium category with tangible factors related to the implementation level is the level conformity procedures.
\end{abstract}

Keywords: adoption, knowledge level, persuasion level, implementation level

\begin{abstract}
ABSTRAK
Pertanian organik terus disosialisasikan kepada para petani namun sampai saat ini masih cukup banyak petani yang tidak mengadopsi pertanian organik. Keputusan petani untuk mengadopsi atau menolak adopsi pertanian organik sayuran dapat dilihat dari tahap proses pengambilan keputusan inovasi. Penelitian ini dilakukan di Desa Ciputri, Kecamatan Pacet, Kabupaten Cianjur. Tujuan penelitian ini adalah menganalisis pengambilan keputusan inovasi pada adopter pertanian sayuran organik dan faktor-faktor yang berhubungan dengan pengambilan keputusan inovasi pada adopter pertanian organik sayuran. Penelitian ini menggunakan metode sensus pada populasi petani yang mengadopsi pertanian organik sayuran dan tetap melanjutkan untuk mengadopsi. Hasil penelitian menunjukkan bahwa tingkat pengetahuan adopter pertanian organik sayuran termasuk pada kategori sedang dengan faktor yang berhubungan nyata dengan tingkat pengetahuan yaitu: luas lahan dan tingkat keberanian mengambil resiko. Pada tingkat persuasi termasuk kategori tinggi dengan faktor yang berhubungan nyata dengan tingkat persuasi yaitu tingkat kesesuaian. Pada tingkat implementasi adopter pertanian organik sayuran termasuk kategori sedang dengan faktor yang berhubungan nyata dengan tingkat implementasi yaitu tingkat kesesuaian prosedur.
\end{abstract}

Kata kunci: adopsi, tingkat pengetahuan, tingkat persuasi, tingkat implementasi 


\section{PENDAHULUAN}

Pertanian organik telah dikenal lama di Indonesia namun masih cukup banyak petani yang belum menerapkan atau mengadopsi sistem pertanian tersebut dalam usahatani mereka. Beberapa tahun lalu perkembangan pertanian organik di Indonesia mengalami penurunan. Berdasarkan data Statistik Pertanian Organik Indonesia (SPOI) tahun 2011 luas kawasan organik mengalami peningkatan 10 persen dari 217.823,19 hektar pada 2009 menjadi 238.872,24 hektar pada 2011 dan pada tahun 2013 kembali mengalami penurunan. Pada tahun 2013, pertumbuhan pangan organik nasional ternyata mengalami penurunan dengan hanya mencapai lima persen. Menurut berita yang dilansir dari Indonesia Organic dan beberapa media massa, nama Indonesia sebagai produsen pangan organik absen dari data IFOAM tahun 2013. Kurang bertumbuhnya pertanian organik di Indonesia dikarenakan pertanian organik masih dilakukan dalam skala kecil dan belum menjadi produksi dalam skala nasional. Pertanian organik perlu terus disosialisasikan kepada para petani di Indonesia sebagai produsen hasil pertanian untuk mengurangi bahkan mengatasi dampak negatif dari penggunaan teknologi pertanian berbahan kimia. Pertanian organik dapat dijadikan sebagai sebuah inovasi pertanian meskipun pada kenyataannya pertanian organik bukan hal baru.

Kesadaran akan bahaya pertanian berbahan kimia bagi keberlanjutan kehidupan, desakan permintaan pasar internasional yang semakin menginginkan produk pertanian yang bebas dari residu bahan kimia sintetik dan kesadaran akan pentingnya makanan sehat bagi tubuh menjadi alasan atau faktor-faktor yang mendorong berkembangnya pertanian organik. Sudirman (2013) menjelaskan bahwa penggunaan teknologi pada revolusi hijau yang akrab dengan penggunaan input bahan-bahan kimia telah menimbulkan pencemaran lingkungan, resistensi dan peledakan hama, dan terkontaminasinya hasil pertanian oleh berbagai residu pestisida bahkan mengakibatkan hilangnya independensi para praktisi pertanian, yaitu petani menjadi sangat ketergantungan pada high input technologies. Munculnya konsep pertanian organik menjadi salah satu alternatif penyelesaian dalam menyediakan pangan yang berkelanjutan. Penerapan pertanian organik juga mampu untuk memperbaiki kerusakan yang sudah terjadi. Pertanian organik merupakan sistem pertanian yang menggunakan bahan-bahan alami yang ramah lingkungan sehingga akan menciptakan keberlanjutan ekologi.

Menurut Badan Standarisasi Nasional (2002) pertanian organik adalah sistem manajemen produksi holistik yang meningkatkan dan mengembangkan kesehatan agroekosistem, termasuk keanekaragaman hayati, siklus biologi, dan aktivitas biologi tanah. Pada tahun 2003, Departemen Pertanian membentuk Otoritas Kompeten Pertanian Organik (OKPO) melalui SK Menteri Pertanian No 432/Kpts/OT.130/9/2003 yang bertugas untuk: (1) merumuskan kebijakan pengaturan pengawasan dan pembinaan sistem pangan organik, (2) merancang dan memformasikan sistem dan acuan untuk dijadikan persyaratan wajib dalam pendirian lembaga sertifikasi pangan organik, dan (3) melakukan verifikasi terhadap lembaga sertifikasi dan atau badan usaha yang menerapkan sistem jaminan mutu pertanian organik dalam program sertifikasi. Pemerintah Indonesia mengeluarkan kebijakan Go Organic 2010 dalam usaha untuk mendukung berkembangnya trend pertanian organik.

Desa Ciputri, Kecamatan Pacet, Kabupaten Cianjur merupakan salah satu desa yang menerapkan sistem usaha tani organik sayuran. Sebagian petani organik sayuran memulai bertani organik sayuran sejak tahun 2009 dan kelompok tani Mandiri telah terdaftar dalam sertifikasi pertanian organik dari Indonesian Organic Farming Certification (INOCEF) dengan No 099/LSPO-003-IDN/03/14 batas masa berlaku sejak 10 Maret 2014-10 Maret 2017. Komoditi yang dipilih untuk ditanam adalah tanaman hortikultura seperti bayam, brokoli, wortel, kubis, bawang daun, salada, mentimun dan lain sebagainya. Komoditas yang ditanam juga disesuaikan dengan kondisi wilayah tersebut yang tergolong wilayah dataran tinggi.

Pada proses pengambilan keputusan inovasi dipengaruhi oleh beberapa faktor yaitu: saluran komunikasi, karakteristik sosial ekonomi, kepribadian dan persepsi terhadap karakteristik inovasi. Oleh karena itu, dalam tulisan ini akan dilihat bagaimana pengambilan keputusan inovasi pada adopter pertanian organik sayuran serta faktorfaktor apa saja yang berhubungan dengan pengambilan keputusan inovasi? 


\section{PENDEKATAN TEORITIS}

\section{Adopsi Inovasi}

Menurut Rogers (1995) adopsi inovasi merupakan suatu proses mental atau perubahan perilaku baik berupa pengetahuan, sikap dan keterampilan pada seseorang saat mengenal inovasi sampai memutuskan untuk mengadopsi. Teori adopsi inovasi merupakan suatu proses penerimaan atau penerapan suatu inovasi yang dilakukan oleh seseorang atau individu. Rogers (1995) mengkonsepkan lima tahap proses keputusan adopsi inovasi, yaitu:

1. Pengetahuan (knowledge), yaitu ketika individu atau unit pengambilan keputusan lainnya mengetahui adanya inovasi dan memperoleh beberapa pemahaman tentang fungsi inovasi tersebut.

2. Persuasi (persuasion), yaitu ketika individu atau unit pengambilan keputusan lainnya membentuk sikap berkenan atau tidak berkenan terhadap inovasi.

3. Keputusan (decision), yaitu ketika individu atau unit pengambilan keputusan lainnya terlibat dalam kegiatan yang mengarah pada pilihan untuk mengadopsi atau menolak inovasi.

4. Implementasi (implementation), yaitu ketika individu atau unit pengambilan keputusan lainnya mulai menggunakan inovasi.

5. Konfirmasi (confirmation), yaitu ketika individu atau unit pengambilan keputusan lainnya berusaha mencari penguatan dari inovasi yang telah diputuskan atau membalikkan keputusan sebelumnya.

Pada tahap proses keputusan adopsi inovasi terdapat faktor kondisi awal yang dapat mempengaruhinya, antara lain: (1) praktik sebelumnya, (2) kebutuhan atau masalah yang dirasakan, (3) keinovatifan, dan (4) norma-norma. Pada tahap knowlegde (pengetahuan) keputusan individu dipengaruhi oleh faktor unit karakteristik pengambil keputusan. Tahap persuation (persuasi) dipengaruhi oleh faktor persepsi karakteristik inovasi. Selanjutnya tahap decision (keputusan) individu mulai berhadapan pada keputusan untuk mengadopsi atau menolak suatu inovasi kemudian pada tahap implementation (implementasi) dan confirmation (konfirmasi) merupakan tahap proses lanjutan dari apa yang telah individu putuskan pada tahap decision.

\section{Penyuluhan}

Slamet (2003) mendefinisikan penyuluhan pertanian adalah suatu sistem pendidikan luar sekolah (pendidikan non formal) untuk petani dan keluargannya dengan tujuan agar mereka mampu dan sanggup memerankan dirinya sebagai warga negara yang baik sesuai dengan bidang profesinya, serta mampu, sanggup dan berswadaya dalam memperbaiki atau meningkatkan kesejahteraan diri sendiri maupun masyarakat. Menurut UndangUndang RI Nomor 16 Tahun 2006 penyuluhan adalah proses pembelajaran bagi pelaku utama serta pelaku usaha agar mereka mau dan mampu menolong dan mengorganisasikan dirinya dalam mengakses informasi pasar, teknologi, permodalan, dan sumberdaya lainnya, sebagai upaya untuk meningkatkan produktivitas, efisiensi usaha, pendapatan, dan kesejahteraannya, serta meningkatkan kesadaran dalam pelestarian fungsi lingkungan hidup.

Suriatna (1988) mendefinisikan metode penyuluhan pertanian sebagai cara penyampaian materi penyuluhan berdasarkan teknik komunikasi yang dilakukan oleh penyuluh kepada petani atau nelayan beserta keluarganya agar bisa dan membiasakan diri untuk menggunakan teknologi atau inovasi baru. Metode penyuluhan berdasarkan jumlah sasaran yang dicapai digolongkan menjadi tiga, yaitu: (1) metode berdasarkan pendekatan perorangan, (2) metode berdasarkan pendekatan kelompok dan (3) metode berdasarkan pendekatan massal. Menurut Mardikanto (1993) media penyuluhan adalah alat atau benda yang dapat diamati, didengar, diraba, atau dirasakan oleh indera manusia yang berfungsi untuk memperagakan atau menjelaskan uraian yang disampaikan penyuluh agar materi penyuluhan mudah dipahami. Media penyuluhan juga diharapkan dapat menarik perhatian dan menimbulkan kesan mendalam bagi sasaran penyuluhan serta berfungsi sebagai alat bantu yang dapat menghemat waktu yang terbatas. Materi yang disampaikan harus sesuai dengan kebutuhan dari individu petani, dapat memunculkan rasa ingin lebih tahu mendalam dan memotivasi, dapat memecahkan permasalahan yang dialami oleh petani.

\section{Pertanian Organik}

Menurut Saragih (2008) dalam pemahaman praktis, pertanian organik adalah suatu cara bertani yang tidak menggunakan bahan kimia. Secara konteks 
regulasi, pertanian organik merupakan cara berproduksi dan memasarkan hasil produksi sesuai dengan standar yang diatur oleh undang-undang atau kebijakan formal dan akibatnya memiliki kekuatan hukum. Istilah pertanian organik menurut Sutanto (2006) ialah menghimpun seluruh imajinasi petani dan konsumen yang secara serius dan bertanggung jawab menghindarkan bahan kimia dan pupuk yang bersifat meracuni lingkungan dengan tujuan untuk memperoleh kondisi lingkungan yang sehat. Secara keseluruhan, pertanian organik merupakan suatu sistem pertanian yang digunakan untuk menghasilkan produksi tanaman dengan memperhatikan input dan keberlanjutan lingkungan. Istilah pertanian organik dapat dikatakan sebagai suatu gerakan "selaras dengan alam" atau "kembali ke alam".

IFOAM (International Federation of Organis Agriculture Movement) adalah organisasi internasional yang didirikan oleh para aktivis gerakan pertanian organik dari seluruh dunia. Empat Prinsip Pertanian Organik menurut IFOAM dalam Saragih (2008):

(1) Prinsip Kesehatan: Pertanian organik harus melestarikan dan meningkatkan kesehatan tanah, tanaman, hewan, manusia dan bumi sebagai satu kesatuan dan tidak terpisahkan.

(2) Prinsip Ekologi: Pertanian organik harus didasarkan pada sistem dan siklus ekologi kehidupan. Bekerja, meniru, dan berusaha memelihara sistem dan siklus ekologi kehidupan.

(3) Prisip Keadilan: Pertanian organik harus membangun hubungan yang mampu menjamin keadilan terkait dengan lingkungan dan kesempatan hidup bersama.

(4) Prinsip Perlindungan: Pertanian organik harus dikelola secara hati-hati dan bertanggung jawab untuk melindungi kesehatan, kesejahteraan generasi sekarang dan mendatang serta lingkungan hidup.

\section{KERANGKA PEMIKIRAN}

Kerangka pikir dalam penelitian ini adalah sebagai berikut

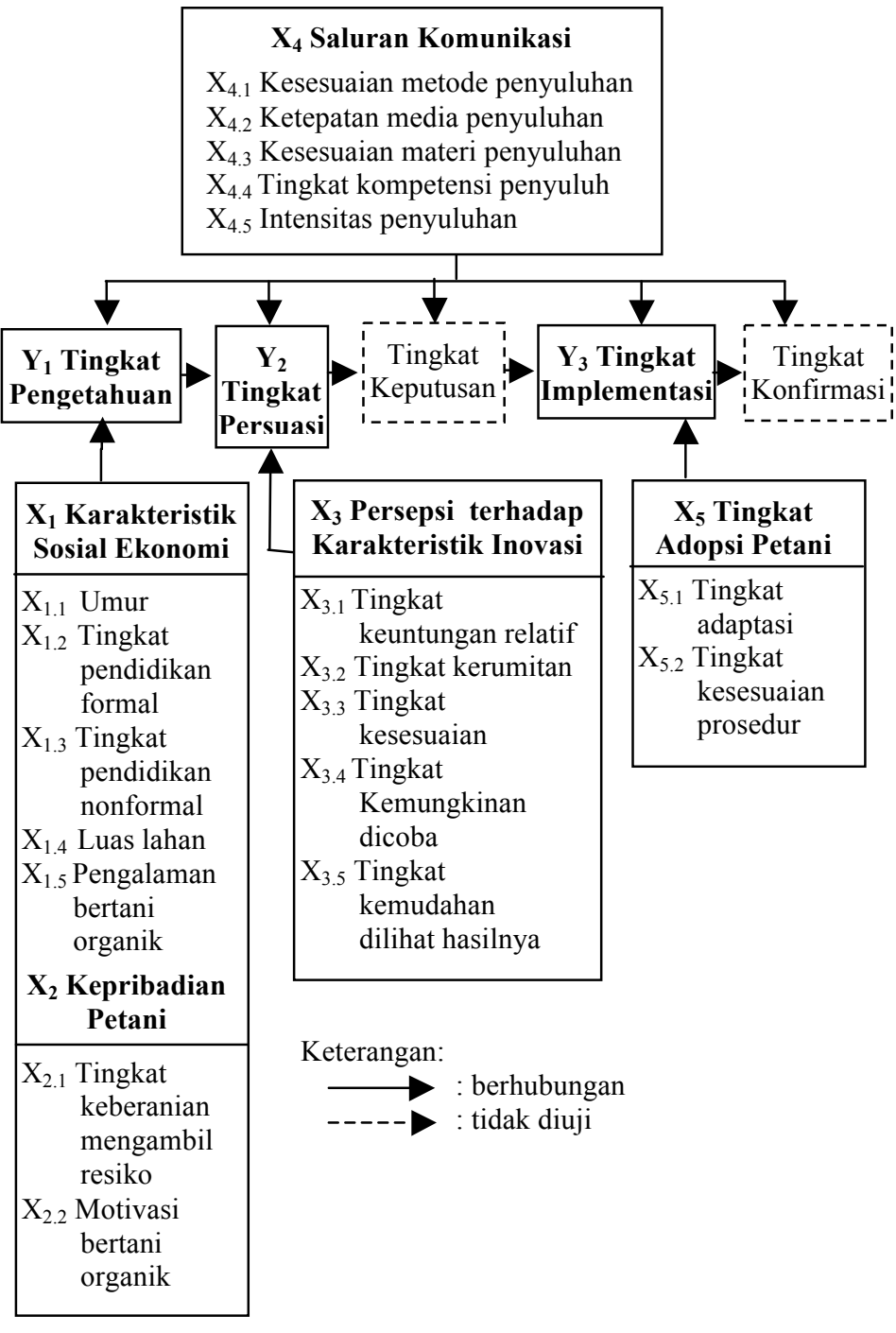

Gambar 1 Kerangka pemikiran

\section{METODE PENELITIAN}

Penelitian ini dilakukan di Desa Ciputri, Kecamatan Pacet, Kabupaten Cianjur, Jawa Barat. Wilayah ini termasuk dalam salah satu wilayah pertanian yang menerapkan pertanian sayuran organik. Kelompok tani organik yang berada di Desa Ciputri, Kecamatan Pacet, Kabupaten Cianjur mendapatkan sertifikasi pertanian organik dari Lembaga Sertifikasi Pertanian Organik INOFICE (Indonesia Organic Farming Sertification) dengan No 099/LSPO-003-IDN/03/14 batas masa berlaku sejak 10 Maret 2014-10 Maret 2017. Pengambilan data dilaksanakan mulai dari April 2015 sampai dengan Mei 2015.

Populasi dalam penelitian ini adalah seluruh petani di Desa Ciputri yang telah mengadopsi pertanian organik sayuran dan tetap melanjutkan mengadopsi. 
Pengambilan responden dilakukan menggunakan metode sensus dengan jumlah responden sebanyak 21 petani organik sayuran. Informan adalah orang yang menceritakan tentang lingkungannya atau pihak-pihak lain yang dapat mendukung informasi dalam penelitian ini. Dalam penelitian ini informannya yaitu letua kelompok Tani Mandiri dan ketua BPP Pacet.

Pengumpulan data pada penelitian ini dilakukan secara kuantitatif dengan instrumen kuesioner yang telah disusun. Kuesioner yang ditanyakan kepada responden terdiri dari lima bagian. Bagian pertama mengenai karakteristik sosial ekonomi dan kepribadian petani, bagian kedua mengenai persepsi terhadap karakteristik inovasi, bagian ketiga mengenai saluran komunikasi, bagian keempat pengambilan keputusan inovasi dan bagian terakhir berkenaan dengan tingkat adopsi petani. Data kualitatif diperoleh melalui wawancara mendalam, data sekunder dan observasi lapang. Hasil pengamatan dari observasi lapang dan wawancara dituangkan dalam bentuk catatan harian dan kutipan langsung. Data sekunder diperoleh melalui literatur yaitu buku-buku, profil desa, maupun dokumen atau informasi tertulis yang terkait dengan fokus penelitian ini.

Teknik pengolahan data yang digunakan yaitu dengan menyederhanakan data yang diperoleh dari kuesioner. Data yang didapat kemudian diolah dengan menggunakan Microsoft Excel 2010 dan disajikan dalam bentuk tabel frekuensi. Untuk melihat hubungan antar variabel data diolah kembali dengan menggunakan uji korelasi rank Spearman pada aplikasi software spss for windows versi 16.0. Alpha yang digunakan dalam uji korelasi adalah sebesar 5\% atau 0,05 yang artinya derajat kebenaran dalam penelitian ini adalah $95 \%$.

Pada penelitian ini uji korelasi dilakukan antara variabel karakteristik sosial ekonomi, kepribadian petani dan saluran komunikasi dengan tingkat pengetahuan, variabel persepsi terhadap karakteristik inovasi, saluran komunikasi dan tingkat pengetahuan dengan tingkat persuasi, variabel tingkat adopsi petani, saluran komunikasi dan tingkat persuasi dengan tingkat implementasi. Hasil data yang diperoleh dari metode kualitatif dengan wawancara mendalam disajikan secara deskriptif. Metode ini digunakan untuk memperkuat data kuantitatif. Selanjutnya semua data yang telah diolah disajikan dalam bentuk narasi kemudian ditarik kesimpulannya.

\section{KARAKTERISTIK SOSIAL EKONOMI}

\section{Umur}

Petani organik di Desa Ciputri sebagian besar adalah petani yang tergolong muda dan masih sangat produktif. Petani yang tergolong pada kategori muda adalah yang berusia $\leq 29$ tahun. Petani lain yang termasuk pada kelompok umur dewasa sangat sedikit yang memilih untuk bertani sayuran secara organik. Petani organik yang berusia muda tersebut adalah petani yang baru memulai untuk bertani organik sayuran. Mereka lebih memilih untuk bekerja di desanya sebagai petani mengikuti orang tua mereka daripada bekerja di luar desa. Sementara itu, petani yang tergolong berusia dewasa I dan II kurang berminat untuk mencoba bertani sayuran secara organik. Hal ini dikarenakan bertani secara konvensional lebih menghasilkan produksi sayuran yang lebih banyak, tidak membutuhkan perawatan yang sulit dan sangat mudah dalam memasarkan sayuran untuk dijual. Pada petani berusia tua cukup sulit untuk mengubah kebiasaan petani yang sebelumnya sejak lama sudah terbiasa bertani sayuran dengan menggunakan bahan-bahan kimia pertanian menjadi beralih pada sistem pertanian tanpa menggunakaan bahan-bahan kimia.

\section{Tingkat Pendidikan Formal}

Tingkat pendidikan formal petani sayuran organik di Desa Ciputri adalah tergolong rendah. Pada tingkat pendidikan formal, porsi terbesar dari petani organik sayuran adalah berpendidikan hanya sampai tamat SD dan hanya sedikit dari petani organik yang menyelesaikan sekolahnya sampai tamat SLTA. Rendahnya tingkat pendidikan petani organik sayuran dikarenakan petani sudah terbiasa dari kecil ikut membantu orang tua bekerja sehingga keinginan mereka untuk bersekolah menjadi berkurang. Selain itu, kondisi ekonomi orang tua yang rendah menjadikan mereka kesulitan untuk menyekolahkan anak-anaknya. 


\section{Tingkat Pendidikan Nonformal}

Tingkat pendidikan nonformal yang dimaksud dalam penelitian ini yaitu kegiatan pelatihan atau penyuluhan mengenai pertanian organik yang pernah diikuti pada setahun terakhir. Tingkat pendidikan nonformal petani organik sayuran di Desa Ciputri termasuk pada kategori rendah. Sebagian besar petani organik hanya pernah mengikuti pelatihan atau penyuluhan sebanyak dua kali. Rendahnya petani organik mengikuti penyuluhan atau pelatihan dikarenakan petani terkadang tidak hadir ketika penyuluhan karena mereka mempunyai kegiatan lain seperti kerja di kebun strawberry, mengantar sayuran ke pasar induk, atau ada keperluan masing-masing. Selain karena ketidakhadiran petani organik pada saat adanya pelatihan atau penyuluhan, diketahui bahwa BPP (Badan Penyuluhan Pertanian) dalam kurun waktu lima bulan terakhir jarang mengadakan kegiatan penyuluhan atau pelatihan. Menurut ketua kelompok tani organik mulai dari awal tahun 2015 sampai bulan Mei 2015 tidak ada kunjungan atau penyuluhan dari Dinas Pertanian atau BPP.

\section{Luas Lahan}

Luas lahan yang digarap oleh petani organik sayuran Desa Ciputri diketahui bahwa sebagian besar petani organik hanya memiliki luas lahan garapan sekitar $\leq 100 \mathrm{~m}^{2}$. Luas lahan garapan petani organik ini tergolong pada kategori tidak luas. Hampir semua lahan petani organik adalah lahan sewaan. Petani organik sayuran menyewa sebidang lahan yang kemudian lahan tersebut dibagi dengan anggota yang lainnya. Untuk sebagian petani organik yang lain, mereka diberikan lahan oleh pihak Green Radio sebagai kegiatan kemitraan. Green Radio merupakan pihak yang bekerja sama dengan petani organik sayuran di Desa Ciputri dalam rangka kepeduliannya terhadap lingkungan. Dengan luas lahan yang sedikit tersebut maka diperlukan jadwal pengaturan pola tanam yang baik sehingga waktu panen tidak bersamaan.

\section{Pengalaman Bertani Organik}

Petani organik sayuran di Desa Ciputri memiliki pengalaman bertani organik yang tergolong kategori rendah. Sebagian besar, petani organik baru sekitar 1-1.5 tahun memulai bertani sayuran organik. Petani yang baru memulai bertani sayuran organik dikarenakan mereka melihat hasil yang didapat oleh petani sebelumnya cukup menguntungkan dan melihat bahwa perkembangan sayuran organik sudah banyak diminati oleh masyarakat. Berdasarkan fakta di lapangan, petani di Desa Ciputri baru memulai bertani organik pada tahun 2009. Ketika itu, hanya 5 orang petani yang baru memulai bertani organik kemudian pada sekitar tahun 2012 petani yang lainnya mulai mengikuti bertani organik. Sebelumnya, petani organik sayuran Desa Ciputri menerapkan pertanian sayuran secara konvensional.

\section{Tingkat Keberanian Mengambil Resiko}

Tingkat keberanian mengambil resiko dilihat dari reaksi petani organik pada saat pertama kali petani mendengar informasi mengenai pertanian organik. Tingkat keberanian mengambil resiko dikalangan petani organik menunjukkan selisih yang sangat kecil. Sebagian besar petani memiliki tingkat keberanian mengambil resiko yang sedang. Petani lebih memilih untuk melihat terlebih dahulu keberhasilan usahatani sayuran organik orang lain sebelum mereka memulai untuk menerapkannya. Akan tetapi, lebih dari 40 persen petani sayuran organik juga memilih untuk mencoba langsung bertani sayuran organik tanpa terpengaruh pada hasil yang diperoleh petani organik lainnya. Petani yang memiliki tingkat leberanian mengambil resiko yang sedang dikarenakan petani baru mencoba atau memulai untuk bertani sayuran secara organik apabila mereka telah mengetahui terlebih dahulu keuntungan dan kesulitan bertani sayuran organik dengan melihat usahatani orang lain. Ketika petani sudah mengetahui bagaimana hasil dari usahatani sayuran organik orang lain maka petani baru akan mencoba menerapkannya.

\section{Motivasi Bertani Organik}

Sebagian besar petani memiliki motivasi bertani organik sayuran yang tergolong rendah. Lebih dari 50 persen petani hanya memilih satu alasan yang melatarbelakangi mereka untuk bertani sayuran secara organik yaitu untuk meningkatkan pendapatan. Alasan petani yang memilih bertani sayuran organik untuk meningkatkan pendapatan dikarenakan tingginya harga jual dari sayuran organik. Hal lain yang mendasari petani dalam bertani organik adalah karena mereka ingin menambah pengalaman dan mencoba sesuatu yang baru yang bisa membuat mereka mendapatkan keuntungan. Diantara semua petani organik sayuran hanya sedikit petani yang mempunyai alasan berusahatani sebagaimana tujuan utama dari 
pertanian organik yaitu memelihara kelestarian lingkungan dan peduli akan kesehatan sebagai motivasi atau alasan utama dalam bertani organik.

\section{PERSEPSI TERHADAP KARAKTERISTIK INOVASI}

\section{Tingkat Keuntungan Relatif}

Keuntungan dalam pertanian organik sayuran dilihat dari aspek hasil produksi, harga jual dan biaya yang dikeluarkan petani organik dalam berusahatani organik sayuran. Sebagian besar petani organik menyatakan bahwa bertani sayuran organik ternyata menguntungkan bagi para petani organik. Keuntungan yang paling dirasakan petani organik ialah dari harga jual sayuran organik yang cukup tinggi jika dibandingkan dengan sayuran yang konvensional. Selain itu, pada aspek produksi, biaya yang dikeluarkan untuk bertani sayuran organik jauh lebih sedikit jika dibandingkan dengan pertanian konvensional. Selain itu, harga jual dari hasil bertani sayuran organik dapat mencapai 2-3 kali lipat daripada harga jual dari hasil bertani konvensional.

\section{Tingkat Kesesuaian}

Sebagian besar petani menganggap bahwa bertani sayuran organik sudah sesuai dan tepat untuk dilakukan. Bertani organik merupakan salah satu usaha untuk mengurangi ketergantungan dengan bahan-bahan kimia pertanian sekaligus untuk menjaga lingkungan dan kesehatan. Petani di Desa Ciputri memutuskan untuk bertani sayuran organik karena melihat perkembangan pertanian organik sayuran yang saat ini sedang banyak diminati masyarakat dan cukup banyak keuntungan yang akan didapat. Meskipun sebagian besar petani organik setuju terhadap pertanian organik namun ada beberapa petani organik yang merasa lebih cocok bertani konvensional.

\section{Tingkat Kerumitan}

Petani organik menyatakan bahwa bertani sayuran secara organik memiliki tingkat kerumitan yang cukup rumit. Kerumitan atau kesulitan dari bertani organik yang dirasakan oleh petani di Desa Ciputri adalah pada proses pembuatan pupuk maupun pestisida organik serta kesulitan dalam memasarkan hasil sayuran organik. Pada proses perawatan, tanaman sayuran organik juga membutuhkan perawatan yang lebih intens karena tanaman sayur tersebut lebih rentan dari gangguan serangan hama.
Apabila terdapat tanaman sayur yang sudah terkena serangan hama maka petani harus lebih sabar dalam menanganinya dikarenakan pengaruh dari penggunaan pestisida nabati tidak secepat penggunaan pestisida kimia. Kesulitan lain yang dirasakan petani organik yaitu pada pemasaran sayuran organik. Hal itu dikarenakan masih banyak konsumen yang kurang tertarik terhadap sayuran organik terutama dari sisi harganya. Harga dari sayuran organik cenderung lebih tinggi jika dibandingkan dengan sayuran konvensional.

\section{Tingkat Kemungkinan Dicoba}

Sebagian besar petani organik di Desa Ciputri menyatakan bahwa bertani sayuran organik sangat mungkin dicoba pada skala kecil. Menurut petani organik, untuk mencoba menerapkan bertani sayuran secara organik tidak harus pada lahan yang luas bahkan dengan memanfaatkan pekarangan rumah juga dimungkinkan untuk ditanam. Pada umumnya bertani sayuran organik dapat dicoba pada semua lahan baik itu pada lahan luas maupun lahan sempit karena yang terpenting tanaman organik tersebut tidak tercemar atau tercampur zatzat kimia. Hampir sebagian besar responden juga mengatakan bahwa pertanian organik sayuran dapat dicoba pada lahan yang luas maupun sempit.

\section{Tingkat Kemudahan Dilihat Hasilnya}

Petani organik sayuran di Desa Ciputri menyatakan bahwa hasil dari sayuran organik mudah untuk dilihat atau dibandingkan dengan sayuran yang ditanam secara konvensional. Jika diamati secara fisik, pada daun sayuran organik dapat ditemukan lubang-lubang akibat gigitan hama, ukuran buah atau sayuran tidak merata dan apabila dikonsumsi sayuran akan terasa manis. Bagi petani organik Desa Ciputri, sayuran organik dengan sayuran konvensional mampu untuk dibedakan karena petani sudah memiliki pengalaman menanam keduanya. Akan tetapi, bagi konsumen untuk membedakan antara sayuran organik dengan yang konvensional mungkin cukup sulit karena konsumen hanya melihat pada hasil akhir dalam bentuk siap untuk dibeli dan dikonsumsi.

\section{SALURAN KOMUNIKASI}

\section{Metode Penyuluhan}

Berbagai metode yang digunakan pada saat penyuluhan menurut sebagian petani dianggap sudah sesuai dan tepat dengan kebutuhan petani. 
Pada umumnya, metode yang digunakan pada saat penyuluhan yaitu seperti metode dialog atau tanya jawab dan metode demonstrasi plot. Metode penyuluhan yang diterapkan harus memberikan ruang kepada para petani untuk turut andil dalam proses penyuluhan yang berlangsung sehingga menciptakan komunikasi dua arah. Bagi petani organik, mereka lebih menyukai teknik dengan cara praktik. Setelah penyuluh memberikan materi, petani diberikan waktu untuk bertanya kemudian petani diajak untuk mencoba mempraktikkannya agar lebih dapat teraplikasikan secara nyata materi yang telah diberikan. Seseorang dapat lebih mudah untuk mengingat apabila orang tersebut telah mencoba atau merasakan sendiri dan lebih mudah lagi apabila mereka melakukannya terus menerus, sebaliknya jika seseorang hanya melihat dan mendengar maka kemungkinan orang tersebut akan lupa lebih besar.

\section{Media Penyuluhan}

Dalam proses penyuluhan, agar materi penyuluhan dapat tersampaikan dengan baik kepada petani maka media yang digunakan harus tepat dengan kebutuhan petani. Sebagian besar petani organik di Desa Ciputri menyatakan bahwa media atau alat bantu yang digunakan pada saat penyuluhan dianggap masih kurang tepat. Pada kegiatan penyuluhan, materi disajikan dalam bentuk slide dan terkadang petani tidak diberikan modul penjelasannya. Menurut petani, untuk lebih membantu petani dalam memahami materi maka penyuluh dapat menambahkan video yang berkaitan dengan materi yang diberikan. Seperti contoh, materi penyuluhan yang dibahas mengenai pembuatan pestisida nabati maka akan lebih baik jika diberikan juga video atau tutorial dari pembuatan pestisida nabati. Hal tersebut dimaksudkan agar petani lebih dapat mengingat dan tergambar tentang materi yang disampaikan.

\section{Materi Penyuluhan}

Sebagian besar petani organik Desa Ciputri menyatakan bahwa materi yang diberikan pada saat penyuluhan maupun pelatihan mengenai pertanian organik dianggap sudah sesuai dengan kebutuhan petani organik. Materi yang disampaikan oleh penyuluh dapat membantu petani organik menambah pengetahuan mereka terhadap pertanian organik sehingga petani menjadi terbantu pada saat bertani sayuran organik. Materi penyuluhan yang diberikan oleh BPP biasanya terlebih dahulu melihat dari apa yang menjadi keluhan atau masalah yang dirasakan oleh petani barulah setelah itu penyuluh memberikan solusinya. Sedangkan materi yang diberikan pada saat pelatihan atau penyuluhan yang diadakan dari luar kecamatan biasanya materimateri seputar teknik-teknik pertanian organik secara umum. Meskipun demikian semua materi yang diberikan dapat memperluas petani dalam hal pertanian organik sayuran khususnya.

\section{Kompetensi Penyuluh}

Kompetensi atau kemampuan penyuluh dalam menguasai dan menyampaikan materi penyuluhan menurut sebagian besar petani sudah tergolong baik. Penjelasan yang dipaparkan penyuluh disampaikan dengan cukup jelas. Agen penyuluh juga terkadang langsung membantu petani organik jika mengalami kesulitan di lahan. Kemampuan agen penyuluh dalam menguasai materi penyuluhan terlihat dari orang-orang yang memberikan penyuluhan yakni mereka yang sudah berpengalaman dan berpengetahuan yang luas dibidang pertanian organik. Selain itu, cara penyampaian materi yang dilakukan oleh agen penyuluh juga sudah tepat karena sesuai dengan kapasitas sasaran penyuluhan dalam menerima informasi tersebut.

\section{Intensitas Penyuluhan}

Sebagian besar petani organik di Desa Ciputri menyatakan bahwa frekuensi atau intensitas penyuluhan pada musim tanam terakhir atau pada kurun waktu lima bulan terakhir tidak berjalan dengan baik. Pada kurun waktu tersebut tidak ada kegiatan penyuluhan atau pelatihan yang diberikan kepada petani sayuran organik di Desa Ciputri. Rendahnya intensitas penyuluhan yang diakibatkan pada musim tanam terakhir tidak ada sama sekali kegiatan penyuluhan dikarenakan aktivitas Badan Penyuluhan Pertanian (BPP) Pacet yang sedang terhambat dengan adanya pergantian struktur kepemimpinan.

Meskipun, intensitas penyuluhan rendah pada kenyataannya tidak terlalu berdampak bagi petani organik karena selama petani masih bisa untuk mengatasi masalah dalam usahataninya maka mereka tidak terlalu bermasalah dengan kegiatan penyuluhan yang jarang dilakukan. Akan tetapi, jika terus menerus tidak ada pemantauan atau kunjungan dari penyuluh atau BPP ke petani maka 
perkembangan pertanian di daerah tersebut tidak akan berkembang.

\section{TINGKAT ADOPSI PETANI}

\section{Tingkat Adaptasi}

Sebagian besar dari petani sayuran organik di Desa Ciputri sangat adaptif artinya petani organik tidak membutuhkan waktu yang lama untuk mengenal dan memahami pertanian sayuran organik. Menurut petani, untuk bertani sayuran organik tidak terlalu sulit karena pada dasarnya mereka memang sudah bertani sayuran namun secara konvensional sehingga petani hanya perlu belajar dan memahami konsep dari bertani organik. Adaptasi petani organik yang tergolong cepat juga dikarenakan kondisi lingkungan yang ada di sekitar petani mendukung. Kondisi lingkungan menjadi salah satu faktor yang mendukung tingkat adaptasi petani yang tinggi terhadap pertanian organik. Seperti fakta di lapangan, petani terbantu dalam penyediaan bahan baku untuk pupuk kandang dan pestisida organik dari urin kelinci karena di desa tersebut terdapat ternak sapi dan kelinci. Oleh karena sudah tersedianya kebutuhan petani untuk bertani sayuran secara organik sehingga petani tidak ragu dan tidak membutuhkan waktu yang lama untuk mulai menerapkannya.

\section{Tingkat Kesesuaian Prosedur}

Petani organik di Desa Ciputri sebagian besar kurang sepenuhnya mengikuti aturan pertanian organik pada saat bertani sayuran organik. Secara umum, petani organik dapat dikatakan sudah sesuai dengan prinsip dalam bertani sayuran organik yaitu dengan tidak menggunakan atau mencampur zat-zat kimia dalam proses produksi. Akan tetapi, jika dilihat secara teknis atau aturan pertanian organik mereka kurang sepenuhnya menerapkan aturan tersebut. Seperti contohnya, pada proses konversi lahan dari sebelumnya lahan pertanian konvensional yang kemudian dialihkan untuk dijadikan sebagai lahan pertanian organik dan pada saat proses pembuatan pupuk kandang maupun pestisida.

\section{Tahap Pengetahuan}

Sebagian besar petani organik di Desa Ciputri memiliki pengetahuan yang tergolong pada kategori sedang. Pada dasarnya, petani organik sudah memiliki pengetahuan mengenai cara atau informasi bertani sayuran organik akan tetapi masih secara umum. Petani tidak sepenuhnya mengetahui informasi tersebut secara spesifik dan rinci. Kurangnya pengetahuan petani mengenai hal-hal yang berkaitan dengan bertani sayuran organik dikarenakan rasa keingintahuan petani yang masih kurang, petani cenderung hanya menerima dan langsung mengikuti. Pada fakta di lapangan, petani organik sudah mengetahui tentang penggunaan pestisida nabati untuk mengendalikan hama pada tanaman sayuran akan tetapi petani tidak mengetahui alasan mengapa bahan-bahan tersebut dipergunakan.

\section{Tahap Persuasi}

Sebagian besar petani sayuran organik dengan jumlah persen lebih dari 85 persen menunjukkan bahwa petani lebih tertarik dan setuju untuk bertani sayuran secara organik. Kecenderungan sikap petani yang lebih memilih untuk bertani sayuran organik dikarenakan sistem bertani organik tidak menggunakan bahan-bahan kimia yang dapat menurunkan kualitas lingkungan maupun kesehatan. Menurut mayoritas petani organik, bertani sayuran organik juga lebih menguntungkan terutama melihat dari perkembangan pertanian organik saat ini yang sudah semakin diminati oleh sebagian masyarakat. Meskipun demikian, teknik bertani secara organik lebih membutuhkan perawatan yang lebih extra jika dibandingkan dengan bertani secara konvensional.

\section{Tahap Keputusan}

Pada tahap keputusan sudah jelas dinyatakan pada bab metode penelitian ini bahwa responden pada penelitian ini adalah seluruh petani yang mengadopsi pertanian organik sayuran dan tetap melanjutkan untuk mengadopsi. Maka dari itu, sudah dipastikan bahwa pada tahap keputusan ini seluruh petani organik di Desa Ciputri memutuskan untuk mengadopsi pertanian organik sayuran. Petani organik sayuran di Desa Ciputri mulai mengadopsi sistem bertani sayuran secara organik pada tahun 2009 dan sebagian lagi mengadopsi pada tahun 2012 sampai saat ini.

\section{Tahap Implementasi}

Dalam penerapan pertanian organik sayuran, petani organik di Desa Ciputri sebagian besar tidak cukup terampil dalam bertani sayuran secara organik. Petani kurang terampil dalam pembuatan pupuk dan pestisida organik terutama dalam pembuatan pestisida nabati. Pada pembuatan pestisida nabati, 
sebagian besar petani hanya mengetahui bahanbahan yang akan digunakan namun petani organik tidak sama sekali bisa untuk membuatnya. Pada pengendalian hama, petani organik rata-rata mampu mengendalikan hama meskipun masih melakukannya secara manual, seperti jika tanaman sayuran mereka terkena serangan hama ulat grayak maka mereka hanya membersihkan ulat-ulat tersebut secara manual. Selain kurang terampilnya petani dalam bertani sayuran organik, petani organik juga masih tidak sepenuhnya melakukan usahatani sayuran organik yang sesuai dengan aturan pertanian organik.

\section{Tahap Konfirmasi}

Pada tahap konfirmasi, petani organik memutuskan untuk tetap melanjutkan untuk mengadopsi pertanian organik sayuran. Petani organik Desa Ciputri terus berusaha untuk mengambangkan usahatani pertanian organik sayuran mereka dengan berusaha untuk lebih mencari informasi mengenai seputar bertani organik sayuran. Fakta yang ada menunjukkan bahwa sampai saat ini petani organik sayuran terus berusaha untuk tetap malanjutkan menerapkan pertanian organik sayuran.

\section{HUBUNGAN ANTARA VARIABEL KARAKTERISTIK SOSIAL EKONOMI, KEPRIBADIAN PETANI DAN SALURAN KOMUNIKASI DENGAN TINGKAT PENGETAHUAN ADOPTER PERTANIAN ORGANIK SAYURAN}

Berdasarkan hasil uji korelasi Rank Spearman diketahui bahwa luas lahan dan tingkat keberanian mengambil resiko ternyata menunjukkan hubungan nyata terhadap tingkat pengetahuan. Berikut tabel hasil uji korelasi Rank Spearman antara variabel karakteristik sosial ekonomi, kepribadian petani dan saluran komunikasi dengan tingkat pengetahuan adopter pertanian organik sayuran.

Hasil penelitian menunjukkan bahwa pada variabel karakteristik sosial ekonomi hanya luas lahan yang menunjukkan hubungan nyata positif dengan tingkat pengetahuan pada pengambilan keputusan inovasi pertanian organik sayuran. Hal itu bermakna bahwa semakin besar luas lahan yang digarap ternyata semakin tinggi tingkat pengetahuan petani organik sayuran. Fakta di lapang, petani dengan luas lahan garapan lebih dari $250 \mathrm{~m}^{2}$ memiliki pengetahuan mengenai informasi seputar sayuran organik lebih banyak, seperti contoh: pengetahuan mengenai tata cara membuat pupuk dan pestisida organik, pemeliharaan maupun cara mengendalikan hama. Selain itu, petani dengan lahan garapan yang lebih luas akan menuntut mereka untuk mengetahui informasi mengenai pertanian organik sayuran.

Tabel 1 Koefisien korelasi antara variabel karakteristik sosial ekonomi, kepribadian petani dan saluran komunikasi dengan tingkat pengetahuan adopter pertanian organik sayuran, tahun 2015

\begin{tabular}{lc}
\hline Variabel Independen & $\begin{array}{c}\text { Tingkat } \\
\text { Pengetahuan }\left(\mathbf{Y}_{\mathbf{1}}\right)\end{array}$ \\
\hline \multicolumn{1}{c}{ Karakteristik Sosial Ekonomi $\left(\mathbf{X}_{\mathbf{1}}\right)$} \\
Umur $\left(\mathrm{X}_{1.1}\right)$ & 0.342 \\
Tingkat pendidikan formal $\left(\mathrm{X}_{1.2}\right)$ & 0.017 \\
Tingkat pendidikan nonformal & 0.121 \\
$\left(\mathrm{X}_{1.3}\right)$ & $\mathbf{0 . 4 6 2 *}$ \\
Luas lahan $\left(\mathrm{X}_{1.4}\right)$ & 0.349 \\
Pengalaman bertani organik $\left(\mathrm{X}_{1.5}\right)$ & \\
\hline \multicolumn{2}{c}{ Kepribadian Petani $\left(\mathrm{X}_{2}\right)$} \\
Tingkat keberanian mengambil \\
resiko $\left(\mathrm{X}_{2.1}\right) \quad \mathbf{0 . 5 2 3} *$ \\
Motivasi bertani organik $\left(\mathrm{X}_{2.2}\right)$ \\
\hline \multicolumn{2}{c}{ Saluran Komunikasi $\left(\mathrm{X}_{\mathbf{4}}\right)$} \\
Metode penyuluhan $\left(\mathrm{X}_{4.1}\right)$ & 0.255 \\
Media penyuluhan $\left(\mathrm{X}_{4.2}\right)$ & 0.070 \\
Materi penyuluhan $\left(\mathrm{X}_{4.3}\right)$ & 0.139 \\
Tingkat kompetensi penyuluh $\left(\mathrm{X}_{4.4}\right)$ & -0.047 \\
Intensitas penyuluhan $\left(\mathrm{X}_{4.5}\right)$ & 0.175 \\
Ket : $\alpha=0,05 \rightarrow$ nyata $* * \alpha=0,01 \rightarrow$ sangat nyata
\end{tabular}

Variabel umur, pendidikan formal, pendidikan nonformal, serta pengalaman bertani organik ternyata tidak menunjukkan hubungan nyata dengan tingkat pengetahuan dalam proses pengambilan keputusan inovasi. Umur ternyata tidak menunjukkan hubungan nyata dengan tingkat pengetahuan dikarenakan sebagian besar petani organik di Desa Ciputri adalah petani yang tergolong kategori umur muda. Petani organik yang tergolong muda rata-rata baru menerapkan pertanian organik sayuran sehingga pengetahuan atau informasi mereka mengenai bertani organik masih tidak cukup luas. Tingkat pendidikan formal petani organik Desa Ciputri termasuk pada kategori rendah sehingga petani kesulitan dalam memahami mengenai informasi maupun teknik seputar pertanian organik. Tingkat pendidikan nonformal yang dalam hal ini dimaksud adalah penyuluhan atau pelatihan ternyata tidak menunjukkan hubungan nyata dikarenakan petani organik jarang mengikuti kegiatan penyuluhan atau pelatihan organik dengan berbagai alasan yang mereka miliki. Penaglaman bertani organik juga ternyata tidak menunjukkan hubungan nyata dengan tingkat pengetahuan. Petani organik di Desa Ciputri 
sebagian besar baru memulai bertani organik kurang dari dua tahun.

Pada variabel kepribadian petani ternyata tingkat keberanian mengambil risiko menunjukkan hubungan nyata dengan tingkat pengetahuan. Sebagian besar petani organik memutuskan untuk bertani sayuran secara organik dengan pertimbangan melihat hasil yang didapat dari petani organik sebelumnya meskipun demikian cukup banyak juga petani yang memilih untuk bertani organik tanpa melihat dari hasil petani organik sebelumnya. Petani organik yang langsung mencoba menerapkan usahatani organik sayuran lebih memiliki risiko kegagalan yang besar, sehingga menuntut untuk mempunyai pengetahuan yang luas terhadap pertanian organik. Motivasi petani organik sayuran Desa Ciputri untuk menerapkan pertanian organik sayuran tergolong rendah. Sebagian besar petani organik memilih untuk bertani sayuran organik karena untuk meningkatkan pendapatan sebab harga jual dari sayuran organik yang tinggi.

Pada variabel saluran komunikasi ternyata tidak ada variabel yang menunjukkan hubungan nyata dengan tingkat pengetahuan. Hal itu karena dari awal tahun bulan Januari-Mei 2015 tidak pernah diadakan kegiatan penyuluhan kepada petani organik Desa Ciputri. Oleh sebab itu, pada variabel saluran komunikasi tidak terlihat hubungan nyata dengan tahap pengambilan keputusan inovasi pertanian organik sayuran terutama pada tahap tingkat pengetahuan, persuasi, maupun implementasi. Meskipun kegiatan penyuluhan tidak pernah diadakan dari awal tahun 2015, namun kenyataannya kegiatan penyuluhan yang dilakukan oleh BPP Pacet telah berlangsung sejak lama bahkan karena diberikan penyuluhan pertanian organik kepada petani sehingga saat ini petani Desa Ciputri memutuskan untuk mengadopsi pertanian organik sayuran.

\section{HUBUNGAN ANTARA VARIABEL PERSEPSI TERHADAP KARAKTERISTIK INOVASI, SALURAN KOMUNIKASI DAN TINGKAT PENGETAHUAN DENGAN TINGKAT PERSUASI ADOPTER PERTANIAN ORGANIK SAYURAN}

Berdasarkan hasil uji korelasi Rank Spearman menunjukkan bahwa tingkat kesesuaian berhubungan nyata positif dengan tingkat persuasi pada adopter pertanian organik sayuran.

Tabel 2 Koefisien korelasi antara variabel persepsi terhadap karakteristik inovasi, saluran komunikasi dan tingkat pengetahuan dengan tingkat persuasi adopter pertanian organik sayuran, tahun 2015

\begin{tabular}{|c|c|}
\hline Variabel Independen & $\begin{array}{c}\text { Tingkat Persuasi } \\
\left(\mathbf{Y}_{2}\right)\end{array}$ \\
\hline \multicolumn{2}{|c|}{ Persepsi terhadap Karakteristik Inovasi $\left(\mathbf{X}_{3}\right)$} \\
\hline Tingkat keuntungan relatif $\left(\mathrm{X}_{3.1}\right)$ & -0.079 \\
\hline Tingkat kesesuaian $\left(\mathrm{X}_{3.2}\right)$ & $0.611 * *$ \\
\hline Tingkat kerumitan $\left(\mathrm{X}_{3.3}\right)$ & -0.088 \\
\hline Tingkat kemungkinan dicoba $\left(\mathrm{X}_{3.4}\right)$ & -0.132 \\
\hline $\begin{array}{l}\text { Tingkat kemudahan dilihat } \\
\text { hasilnya }\left(X_{3.5}\right)\end{array}$ & -0.079 \\
\hline \multicolumn{2}{|c|}{ Saluran Komunikasi $\left(\mathbf{X}_{4}\right)$} \\
\hline Metode penyuluhan $\left(\mathrm{X}_{4.1}\right)$ & 0.075 \\
\hline Media penyuluhan $\left(\mathrm{X}_{4.2}\right)$ & -0.166 \\
\hline Materi penyuluhan $\left(\mathrm{X}_{4.3}\right)$ & 0.331 \\
\hline Tingkat kompetensi penyuluh $\left(\mathrm{X}_{4.4}\right)$ & -0.198 \\
\hline Intensitas penyuluhan $\left(\mathrm{X}_{4.5}\right)$ & 0.198 \\
\hline \multicolumn{2}{|c|}{ Tahap Pengambilan Keputusan } \\
\hline Tingkat Pengetahuan $\left(\mathrm{Y}_{1}\right)$ & 0.079 \\
\hline
\end{tabular}

Pada variabel persepsi terhadap karakteristik inovasi ternyata menunjukkan hubungan sangat nyata dan positif antara tingkat kesesuaian dengan tingkat persuasi. Hampir semua petani organik di Desa Ciputri menyatakan bahwa pertanian organik sayuran sudah sesuai dengan kebutuhan petani terutama dalam hal untuk meningkatkan pendapatan petani. Selain itu, petani organik menganggap bahwa pertanian organik sudah tepat untuk mengurangi pemakaian zat-zat kimia pada proses pertanian di Indonesia.

Keuntungan relatif, kerumitan, kemungkinan dicoba dan kemudahan dilihat hasilnya ternyata tidak menunjukkan hubungan nyata dengan tingkat persuasi. Sebagian besar petani organik menyatakan bahwa bertani organik menguntungkan, pertanian organik juga dianggap cukup sulit namun pertanian organik sangat mungkin untuk dicoba pada lahan yang sempit serta hasil dari bertani organik juga mudah untuk diamati. Akan tetapi, meskipun demikian sikap petani untuk mengadopsi pertanian organik sayuran bukan dari faktor keuntungan, kerumitan, kemungkinan dicoba dan kemudahan dilihat hasilnya melainkan lebih karena kesesuaian pertanian organik dengan kebutuhan petani, penerapan dari sistem pertanian sebelumnya dan karena sesuai untuk menjaga lingkungan dan peduli terhadap kesehatan. 
Sebagaimana yang telah dijelaskan sebelumnya bahwa variabel saluran komunikasi ternyata tidak menunjukkan hubungan nyata dengan tahap pengambilan keputusan pada adopter pertanian organik sayuran. Hal itu dikarenakan intensitas penyuluhan pada lima bulan terakhir (Januari-Mei) tergolong rendah sehingga pada saat pengambilan data menjadi terbatas hanya pada data kurun waktu lima bulan tersebut. Akan tetapi, metode dan materi penyuluhan pada tahun sebelumnya dianggap sudah cukup baik dan sesuai dengan kebutuhan maupun kemampuan petani organik. Media penyuluhan bernilai negatif karena menurut sebagian petani organik media yang digunakan pada saat berlangsungnya penyuluhan kurang mampu untuk membuat petani lebih ingat terhadap materi yang diberikan. Petani lebih mampu untuk mengingat sesuatu apabila petani melihatnya secara langsung atau dalam bentuk media video atau film. Kemampuan penyuluh juga bernilai negatif dengan tingkat persuasi karena sebagian besar petani yang memilih untuk bertani organik sayuran tidak karena pengaruh dari penyuluh melainkan dari pengaruh pasar. Permintaan konsumen akan pertanian organik saat ini yang cukup tinggi dan harga sayuran organik yang menguntungkan petani menjadi faktor yang membuat petani untuk menerapkan pertanian organik sayuran. Selain itu, variabel tingkat pengetahuan ternyata tidak menunjukkan hubungan nyata dengan tingkat persuasi pada adopter pertanian organik sayuran.

\section{HUBUNGAN ANTARA VARIABEL TINGKAT ADOPSI PETANI, SALURAN KOMUNIKASI DAN TINGKAT PERSUASI DENGAN TINGKAT IMPLEMENTASI ADOPTER PERTANIAN ORGANIK SAYURAN}

Berdasarkan dari hasil uji korelasi menunjukkan bahwa tingkat kesesuaian prosedur berhubungan nyata dengan tingkat implementasi. Berikut adalah tabel koefisien korelasi antara variabel tingkat adopsi petani, saluran komunikasi dan tingkat persuasi dengan tingkat implementasi adopter pertanian organik sayuran.

Tingkat kesesuaian prosedur pada variabel tingkat adopsi petani ternyata menunjukkan hubungan nyata positif dengan tingkat implementasi. Petani organik di Desa Ciputri cenderung tidak sepenuhnya menerapkan pertanian organik sesuai dengan prosedur atau aturan pertanian organik.
Tingkat implementasi petani organik juga tergolong pada kategori sedang. Dalam bertani organik petani sering mengabaikan ketentuan yang telah ditetapkan, seperti contoh dalam membuat pupuk kandang, petani organik hanya menyimpan kotoran hewan yang akan dijadikan sebagai pupuk hanya dalam waktu 2-3 hari sedangkan ketentuan yang sebenarnya yaitu kurang lebih tujuh hari begitu juga hal yang sama pada saat petani organik membuat pestisida hewani. Tingkat adaptasi ternyata tidak menunjukkan hubungan nyata dengan tingkat implementasi, hal itu dikarenakan meskipun adaptasi petani tergolong cepat namun hal demikian tidak menjadikan petani lebih baik dalam mengaplikasikan pertanian organik sayuran.

Tabel 3 Koefisien korelasi antara variabel tingkat adopsi petani, saluran komunikasi dan tingkat persuasi dengan tingkat implementasi adopter pertanian organik sayuran, tahun 2015

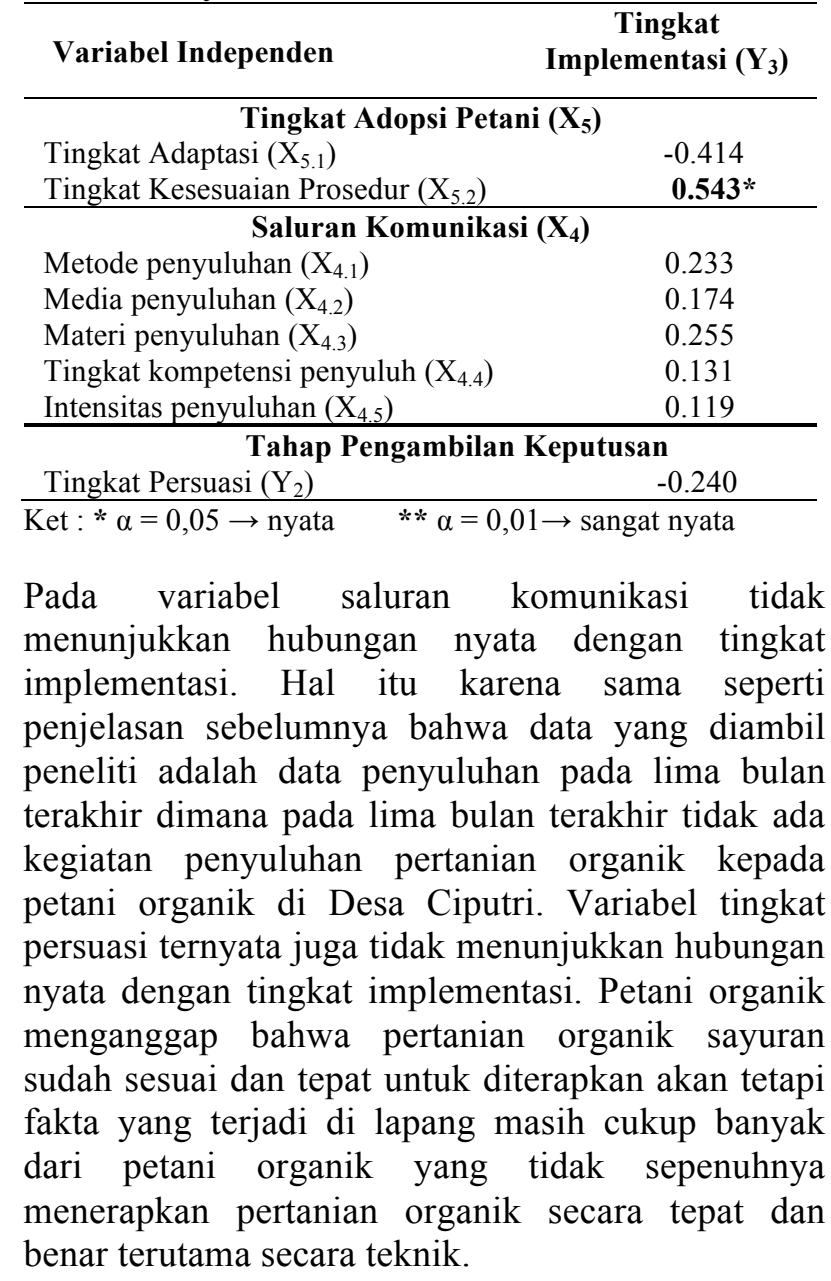




\section{SIMPULAN DAN SARAN}

\section{Simpulan}

Pengambilan keputusan inovasi pada adopter pertanian organik sayuran pada tahap tingkat pengetahuan ternyata tergolong sedang, sikap petani terhadap pertanian organik sangat tertarik dan pada saat petani mulai menerapkan pertanian organik, petani organik ternyata kurang terampil dan tidak sepenuhnya sesuai dengan aturan pertanian organik dalam bertani sayuran organik.

Faktor-faktor yang berhubungan nyata positif dengan tingkat pengetahuan petani organik sayuran dalam pengambilan keputusan adalah luas lahan dan tingkat keberanian mengambil risiko. Semakin luas lahan yang digarap petani dan semakin besar keberanian petani dalam mengambil risiko ternyata semakin tinggi tingkat pengetahuan petani mengenai informasi pertanian organik sayuran. Pada tahap tingkat persuasi ternyata tingkat kesesuaian inovasi menunjukkan hubungan nyata positif dengan tingkat persuasi. Semakin sesuai inovasi pertanian organik sayuran dengan kebutuhan petani ternyata semakin positif dan tertarik sikap petani terhadap pertanian organik sayuran. Pada tahap tingkat implementasi, tingkat kesesuaian prosedur ternyata menunjukkan hubungan nyata positif. Semakin tidak sesuai prosedur petani dalam menerapkan pertanian organik sayuran ternyata semakin kurang baik petani dalam mengaplikasikan atau menerapkan pertanian organik sayuran.

\section{Saran}

Untuk meningkatkan pengetahuan dan implementasi petani dalam proses pengambilan keputusan inovasi maka diperlukan kegiatan seperti mengadakan berbagai pelatihan-pelatihan yaitu antara lain: pembuatan pupuk atau pestisida organik, PHT dan lain sebagainya. Mengadakan kunjungan ke petani sayuran organik lain maupun lembaga atau perusahaan sayuran organik sehingga petani dapat saling berbagi informasi mengenai pertanian sayuran organik diantara sesama petani organik.

Pemerintah perlu terus melakukan sosialisasi mengenai pangan organik baik kepada masyarakat maupun ke petani melalui kegiatan penyuluhan pangan organik, gerakan-gerakan cinta organik atau gerakan back to nature untuk meningkatkan kesadaran masyarakat dan petani akan pentingnya pangan aman dan sehat.

\section{DAFTAR PUSTAKA}

Badan Standarisasi Nasional (BSN). 2002. Sistem Pangan Organik. Jakarta (ID): Kementerian Pertanian.

Indraningsih Kurnia Suci. 2010. Penyuluhan Pada Petani Marjinal: Kasus Adopsi Inovasi Usahatani Terpadu lahan Kering Di Kabupaten Cianjur dan Kabupaten Garut Peovinsi Jawa Barat [disertasi]. Bogor (ID): Institut Pertanian Bogor. [Internet]. [diunduh tanggal 25 September 2014]. Dapat diunduh dari: http://repository.ipb. ac.id/handle/123456789/55076

Republik Indonesia. 2006. Undang-undang RI Nomor 16 Tahun 2006 tentang Sistem Penyuluhan Pertanian, Perikanan, dan Kehutanan. Jakarta (ID): Sekretariat Negara. [Internet]. [diunduh tanggal 19 desember 2014]. Dapat diunduh dari: http://www.bpkp.go.id/uu/filedownload/2/37/ 193.bpkp

Rogers Everett M. 1995. Diffusion of Innovation. USA: The Free Press.

Sadono Dwi. 2008. Pemberdayaan Petani: Paradigma Baru Penyuluhan Pertanian Di Indonesia. JP. [Internet]. [diunduh tanggal 3 September 2014]. 4(1): 65-74. Dapat diunduh dari: http://repository.ipb.ac.id/ handle/123456789/43076

Saragih Sebastian Eliyas. 2008. Pertanian organik. Bogor (ID): Penebar Swadaya.

Slamet Margono. 2003. Pemberdayaan Masyarakat. Dalam Membentuk Pola Perilaku Manusia Pembangunan. Penyunting: Ida Yustina dan Ajat Sudrajat, Bogor: IPB Press.

Sudirman Saadah Jr. 2013. Pengaruh Metode Penyuluhan dan Pengetahuan Tentang Lingkungan terhadap Sikap Petani pada Pertanian Organik. Makassar (ID): Universitas Hasanuddin. [Internet]. [diunduh tanggal 19 Desember 2014]. Dapat diunduh dari: ac.id/handle/123456789/8307

Suriatna Sumardi. 1988. Metode Penyuluhan Pertanian. Jakarta (ID): Sarana Perkasa.

Sutanto Rachman. 2006. Pertanian Organik Menuju Pertanian Alternatif dan Berkelanjutan. Yogyakarta (ID): Kanisius. 
Mardikanto Totok. 1993. Penyuluhan Pembangunan Pertanian. Surakarta (ID): Sebelas Maret University Press.

Zulvera. 2014. Faktor Penentu Adopsi Sistem Pertanian Sayuran Organik dan Keberdayan Petani Di Provinsi Sumatera Barat [disertasi]. Bogor (ID): Institut Pertanian Bogor. [Internet]. [diunduh tanggal 13 November 2014]. Dapat diunduh dari:

http://repository.ipb.ac.id/bitstream/handle/12 3456789/70102/2014zul1.pdf?sequence $=1$ 